\title{
In situ Testing of Biologically Active Dietary Supplement Hepar Formula in Children With Chronic Viral Hepatitis
}

\author{
Vekovtsev A.A. ${ }^{1, *}$ Pleshkova N.A. ${ }^{2}$ Avstrievskikh A.N. ${ }^{1}$ Poznyakovsky V.M. ${ }^{3}$
}

\author{
${ }^{1}$ Artlife LLC, 8/2, Nahimov Str., Tomsk, 634034, Russia \\ ${ }^{2}$ Department of Management named after I.P. Povarić, Kemerovo State University, 6, Krasnaya Str., Kemerovo, \\ 650000, Russia \\ ${ }^{3}$ REC Processing of Agricultural Raw Materials and Food Technologies, Kuzbass State Agricultural Academy, 5, \\ Markovtseva Str., Kemerovo, 650056, Russia \\ *Corresponding author. Email: aquaphorkuz@mail.ru
}

\begin{abstract}
A new type of biologically active dietary supplement - BADS Hepar Formula was developed. The composition of BADS was justified, which proved to have synergistic properties forming a balanced complex for the maintenance of liver metabolic processes, protection and restoration of its cells in conditions of pathological changes. A possible mechanism of participation of functional ingredients of the developed product in relation to metabolic processes in liver diseases is presented. The purpose of the study is to carry out in situ tests of Hepar Formula among children with chronic viral hepatitis. Clinical evidence of functional properties of the new type of biologically active dietary supplement is provided. The therapeutic efficacy of the developed product is studied by including BADS in the diet of 20 children aged 9 to 14 years with chronic viral hepatitis $\mathrm{B}$ and $\mathrm{C}$ in the integration phase of the infectious process. Clinical symptoms were investigated in the dynamics of dietary therapy. By the end of the treatment, good and satisfactory results were reported in $90 \%$ of the children of the main group and $80 \%$ of the control group. The developed product contributes to the improvement of adaptation capabilities of the child's body. Side effects in the application of BADS Hepar Formula are not noted, which is essential for pediatric practice. It is possible to combine the developed product with other drugs. The results of in situ tests showed that the inclusion of BADS into the baseline therapy contributes to reparative processes in liver cells, accelerates tissue regeneration after inflammatory diseases, improves the general condition, has hepatoprotective and anti-inflammatory effects. The new kind of hepatoprotector can be used in prevention and complex treatment of chronic liver diseases. The opinion of the Expert Council of the Russian Federation was received, the developed product is included into the Federal BADS Register.
\end{abstract}

Keywords: biologically active dietary supplement, chronic viral hepatitis, Hepar Formula

\section{INTRODUCTION}

Biologically active dietary supplements (BADS) are becoming ever more popular as an auxiliary dietary therapy for prevention and complex treatment of various diseases, taking into account their mild, prolonged effect on the correction of metabolic disorders and absence of side effects $[1,3,10,14,18-20]$.

The treatment and prevention of hepatobiliary system is an urgent task of modern pediatrics. There is a significant increase in the incidence of liver diseases of viral, toxic and medicinal etiology in children $[2,4,6,9,12]$. In this regard, the importance of both antiviral and systemic therapy has increased - detoxifying, metabolic, membrane-stabilizing, etc., including non-therapeutic methods, one of which is nutrition factor [5, 11, 13, 15-17].

A new kind of hepatoprotector is developed - BADS Hepar Formula, the recipe composition of which proved to have synergistic properties forming a balanced complex for the maintenance of liver metabolic processes, 
protection and restoration of its cells in conditions of pathological changes (Figure 1).

A possible mechanism of participation of functional ingredients of the developed product in relation to metabolic processes in liver diseases is shown in Figure 2.

Ingredients included in the formula of the specialized Hepar Formula have proved themselves both in traditional and scientific medicine as hepatoprotectors, agents of complex therapy of chronic hepatitis, hepatosis, toxic liver damages, etc. $[7,8]$.

\section{PURPOSE OF THE STUDY}

The purpose of the study is to perform in situ tests of a new type of specialized product - biologically active dietary supplement Hepar Formula in children with chronic viral hepatitis.

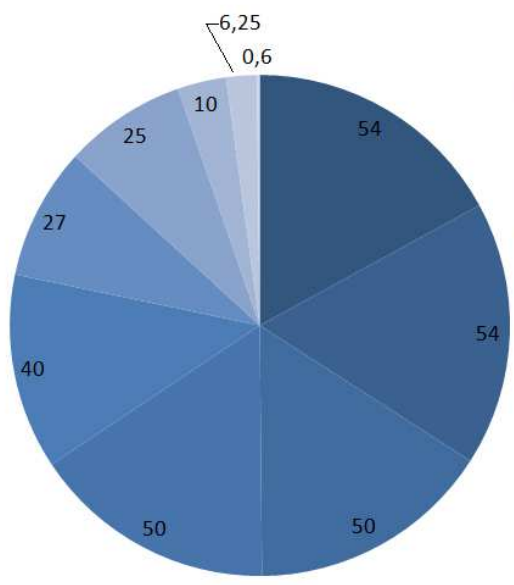

Artichoke (root)

Blessed thistle

Choline

Inositol

Lecithin

Hill-growing saltwort extract

L-methionine

Turmeric

Silimarin (thistledown extract)

Vitamin B6 (pyridoxin)

Figure 1 Composition of BADS Hepar Formula, mg/1 pill (pill weight - 500 mg).

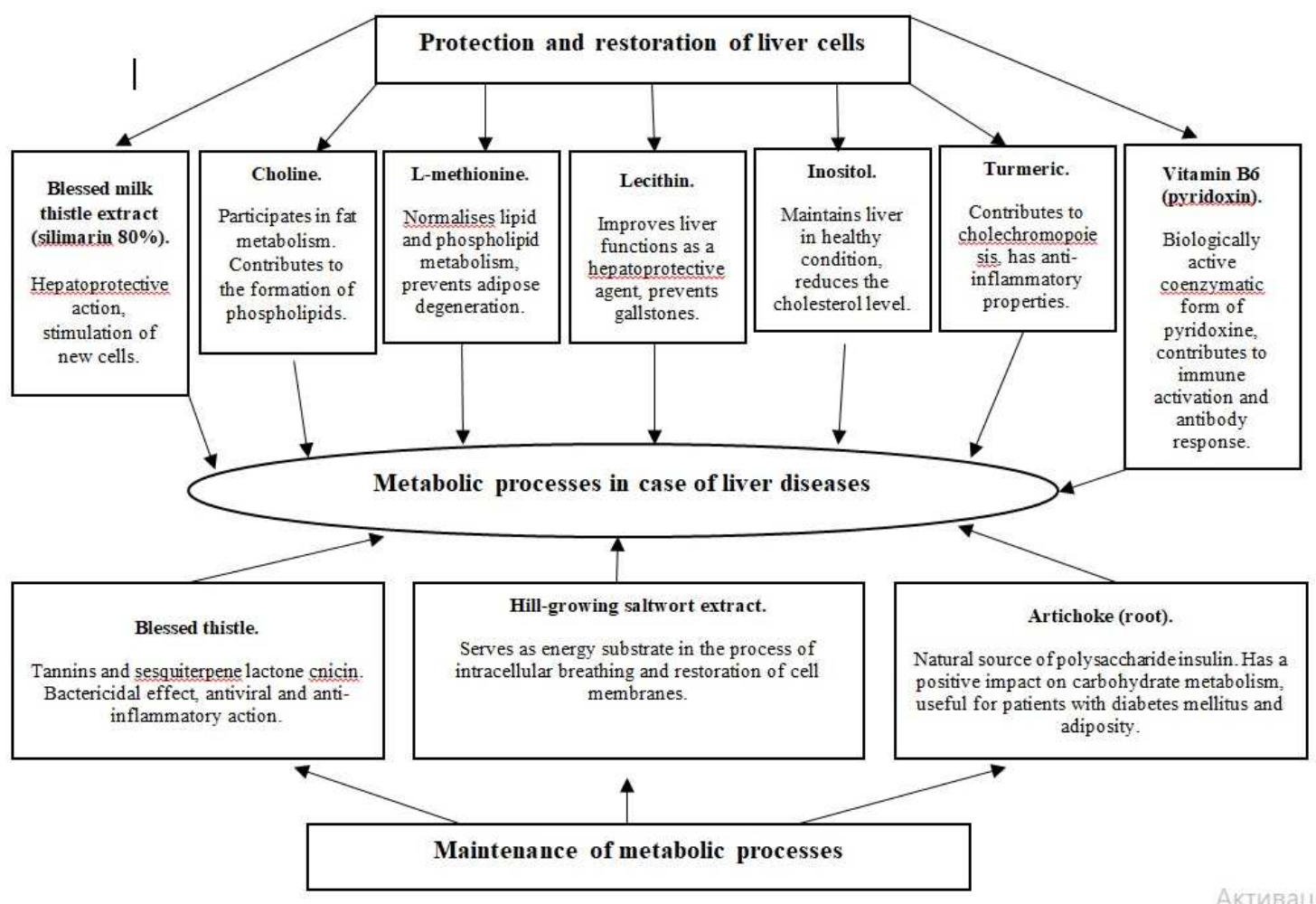

Figure 2 Mechanism of Hepar Formula participation in metabolic processes correlation in liver diseases

\section{MATERIALS AND METHODS}

The therapeutic efficacy of the developed product was studied by including BADS in the diet of 20 children aged
9 to 14 years with chronic viral hepatitis $\mathrm{B}$ and $\mathrm{C}$ in the integration phase of the infectious process.

The diagnosed chronic hepatitis $\mathrm{B}$ (CHB) and chronic hepatitis $\mathrm{C}$ (CHC) was established on the basis of complaints, history data, instrumental and laboratory results: 
- ultrasonography,

- Doppler sonography,

- biochemical blood count,

- detection of virus replication markers.

After verification of the diagnosis by randomization, the children were divided into 2 groups. The first (I) - control group (10 people), received the baseline therapy:

- diet No. 5;

- relaxed day regimen;

- thistle medicines;

- vitamin and antioxidant preparations.

The second (II) - main group (10 people), was prescribed Hepar Formula instead of drug therapy in agespecific dosage variances:

- children from 9 to 12 years - 1/2 pill 2 times a day 30 minutes before meals;

- children above 12 years old - 1 pill 2 times a day.

The length of treatment was 24 days. The clinical efficacy was assessed in graded form using 2 criteria clinical and biochemical.

The positive effect was characterized by the absence of the main clinical manifestations of the disease and normalization of indicators showing the inflammatory process activity in the liver:
- satisfactory - presence of positive clinical dynamics with increased values of cytolysis and bilirubin syndrome in blood serum;

- unsatisfactory - absence of clinical dynamics and changed indices of functional state of liver.

The activity of the inflammatory process was analyzed by the indicators of cytolysis syndrome. The characteristic of clinical manifestations of the disease in the dynamics of treatment was given according to an alternative characteristic - presence or absence of symptoms.

The work was carried out on the basis of the Department of Gastroenterology of the Institute of Pediatrics, Obstetrics and Gynecology of the National Academy of Medical Sciences of Ukraine under the supervision of the Doctor of Medical Sciences, Professor M.F. Denisova.

The parents of the children participating in the study received were fully aware of its nature and confirmed their consent to participation.

\section{RESULTS AND DISCUSSION}

The frequency of complaints, sign symptoms of $\mathrm{CH}$ and laboratory results are shown in Table 1 . Compared to the norm, in all patients before treatment ALAT increased to 1.5-2 norms, in $20 \%$ of children of both groups hyperbilirubinemia (up to $50 \mathrm{mmol} / \mathrm{l}$ ).

Table 1 Rate of clinical symptoms in children with $\mathrm{CH}$ of the main and control groups in treatment dynamics $(\%)$

\begin{tabular}{|c|c|c|c|c|}
\hline \multirow[t]{2}{*}{ Symptoms } & \multicolumn{2}{|c|}{ Control group } & \multicolumn{2}{|c|}{ Main group } \\
\hline & Before treatment & After treatment & Before treatment & After treatment \\
\hline $\begin{array}{l}\text { Asthenic: } \\
\text { - weakness } \\
\text { - fatigability } \\
\text { - irritation } \\
\text { - appetite disorders }\end{array}$ & $\begin{array}{c}100 \\
100 \\
90 \\
60\end{array}$ & $\begin{array}{l}60 \\
30 \\
30 \\
20\end{array}$ & $\begin{array}{c}100 \\
100 \\
90 \\
50\end{array}$ & $\begin{array}{l}10 \\
10 \\
10 \\
-\end{array}$ \\
\hline $\begin{array}{l}\text { Abdominal: } \\
\text { - right subcostal tightness } \\
\text { - right subcostal pain }\end{array}$ & $\begin{array}{l}80 \\
20\end{array}$ & $\begin{array}{c}10 \\
-\end{array}$ & $\begin{array}{l}70 \\
20\end{array}$ & - \\
\hline $\begin{array}{l}\text { Dyspeptic: } \\
\text { - eructation } \\
\text { - bitter taste in mouth, dry mouth } \\
\text { - loose stool }\end{array}$ & $\begin{array}{l}80 \\
60 \\
30 \\
\end{array}$ & $\begin{array}{l}20 \\
40 \\
10\end{array}$ & $\begin{array}{l}80 \\
60 \\
40 \\
\end{array}$ & $\begin{array}{c}10 \\
10 \\
- \\
\end{array}$ \\
\hline Hepatomegalia & 100 & 50 & 100 & 40 \\
\hline Increase of transaminase level in blood serum & 100 & 20 & 100 & 20 \\
\hline Hyperbilirubinemia & 20 & - & 20 & - \\
\hline $\begin{array}{l}\text { The analysis of clinical symptom dynamic } \\
\text { that after the end of the treatment course } 90 \% \\
\text { of the main and control groups showed an impro } \\
\text { the general condition, primarily due to: } \\
\text { - prevention of pain and dyspeptic (nause }\end{array}$ & $\begin{array}{l}\text { showed } \\
\text { children } \\
\text { ement in }\end{array}$ & $\begin{array}{l}\text { - } \begin{array}{l}\text { restoration } \\
\text { - } \\
\text { feduction o }\end{array} \\
\text { The experimentility } \\
\text { logically active d }\end{array}$ & $\begin{array}{l}\text { of appetite; } \\
\text { f asthenia symptom } \\
\text {, weakness, low phy } \\
\text { is showed the } \\
\text { lietary substance o }\end{array}$ & $\begin{array}{l}\text { - increased } \\
\text { sical activity. } \\
\text { nfluence of the } \\
\text { the dynamics of }\end{array}$ \\
\hline
\end{tabular}


decreasing asthenic and dyspeptic syndrome. The analysis of the paraclinic examination of children with chronic viral hepatitis showed that $80 \%$ of them demonstrated a significant decrease in ALAT activity and total bilirubin. There were no significant differences at the end of the treatment in the main and control groups ( $p>0.05)$.

the studied clinic-paraclinic symptoms remained without positive dynamics for 24 days in one patient of the main group with moderately active $\mathrm{CHB}$ and in 2 children with $\mathrm{CHB}$ and $\mathrm{CHC}$ of the control group.

The inclusion of the biologically active Hepar Formula complex in the baseline therapy allowed normalizing the liver size in $60 \%$ of children, which is confirmed by ultrasound data.

By the end of the treatment, good and satisfactory treatment results were reported in $90 \%$ of the children of the main group and $80 \%$ of the control group. No side effects were observed when Hepar Formula was used.

\section{CONCLUSION}

The inclusion of BADS Hepar Formula in the baseline therapy of chronic hepatitis $\mathrm{B}$ and $\mathrm{C}$ at the stage of virus integration decreases the asthenic and dyspeptic syndrome, improves the general condition, has hepatoprotective and anti-inflammatory effect, supports reparative processes in liver cells, accelerates tissue regeneration after inflammatory diseases. It is critical for pediatric practice that Hepar Formula has no side effects, gives the possibility of combining it with other drugs, provides the ability to increase the adaptation capabilities of a child's body.

The received materials are consistent with the conclusion of the Expert Council of the Russian Federation related to the inclusion of BADS into the Federal Register: the specialized product Hepar Formula supports liver metabolic processes, contributes to the protection and restoration of its cells in conditions of pathological changes, improves the general condition, has hepatoprotective and anti-inflammatory effects. Hepar Formula can be used in prevention and complex treatment of chronic liver diseases.

Competitive advantages of the developed biologically active complex are as follows:

- Hepar Formula performs hepatoprotective functions based on a balanced complex of vegetable-based ingredients;

- Hepar Formula helps to eliminate food deficiency of essential phospholipids necessary for protection and restoration of liver tissue, increases life expectancy of cell membranes.

BADS Hepar Formula is produced at the enterprises of ArtLife company (Tomsk), certified according to the international standards ISO 22000:2005, which contributes to stable quality and ensures competitiveness of the developed bioactive complex.

\section{REFERENCES}

[1] N.N. Besednova, S.P. Kryzhanovsky, T.N. Zvyagintseva et al., Seaweed polysaccharides in the correction of disorders associated with metabolic syndrome, Antibiotics and chemotherapy 64(3-4) (2019) 59-70.

[2] N.N. Besednova, T.S. Zaporozhets, T.A. Kuznetsova et al., Hepatoprotective effects of seaweed extracts and polysaccharides, Antibiotics and chemotherapy 59(3-4) (2014) 30-37.

[3] N.D. Bunyatyan, E.A. Kalko, S.M. Drogovoz, A.V. Kononenko, Chronopharmacological features of hepatoprotectors in the experiment, Bull. of Experim. Biol. and Med. 165(6) (2018) 712-715.

[4] A.A. Vekovtsev, B. Tohiriyon, G.V. Slizovsky, V.M. Poznyakovsky, Clinical trials of the vitaminmineral complex for the treatment of children with a trauma profile, Proc. of Voronezh State Univer. of Engineer. Technol. 81(2) (2019) 147-153. Retrieved from: https://doi.org/10.20914/2310-1202-2019-2$147-153$

[5] A.A. Vekovtsev, B. Tohiriyon, A.A. Chelnakov, V.M. Poznyakovsky, Evidence of efficiency and functional orientation of specialized production of clinical trials, Person. Sport. Med. 17(3) (2017) 94101.

[6] E.A. Galova, N.N. Karyakin, Y.N. Filippov et al., Incidence of acute viral hepatitis in children living in the Nizhny Novgorod region, Pediatrics. Journal named after G.N. Speransky 96(4) (2017) 194-198.

[7] E.O. Ermolaeva, N.A. Pleshkova, A.N. Avstrievskikh, Development and assessment of quality Alkoneutral BADS, Food industry 4 (2010) 53.

[8] E.T. Zhilyakova, Z.E. Tsvetkova, D.I. Pisarev et al., Intensification of the production of thick extract of thistle fruits with the use of ultrasonic treatment of raw materials, Pharmacy and pharmacol. 6(5) (2018) 475-487.

[9] A.M. Zaprudnov, K.I. Grigoriev, L. Kharitonov et al., Problems and prospects of modern children gastroenterology, Pediatr. J. named after G.N. Speransky 95(6) (2016) 10-18.

[10] I.V. Zverkov, O.N. Minushkin, Place of combined hepatoprotectors in the treatment of drug-induced hepatitis (DIH) with dyslipidemia, Gastroenterol. of St. Petersburg 2 (2018) 67-67.

[11] I.V. Zverkov, O.N. Minushkin, Do we need hepatoprotectors in the treatment of drug-induced hepatitis (DIH)? Gastroenterol. of St. Petersburg 1 (2017) 81-81b.

[12] E.V. Kostyrko, P.V. Schumilov, N.E. Shchigoleva, Analysis of effectiveness of therapy of autoimmune liver diseases in children, Pediatr. J. named after G.N. Speransky 96(6) (2017) 57-63.

[13] M.L. Maksimov, T.S. Shindina, O.E. Kropova, Hepatoprotective and infusion therapy of patients with inflammatory liver diseases, Russ. Med. J. Med. rev. 2(7-2) (2018) 82-87.

[14] N.A. Pleshkova, A.N. Avstrievskikh, V.M. Poznyakovsky, Regulated technological parameters of production in the formation of consumer properties of a functional product, Food industry 8 (2018) 80-82. 
[15] E.I. Sas, V.B. Grinevich, Multicomponent infusion hepatoprotectors in drug liver damage, Med. council 3 (2019) 84-88.

[16] O.G. Tereshchenko, E.D. Nikolskaya, O.A. Zhunina et al., Production of promising polymeric forms of hepatoprotectors based on silybin and ursodeoxycholic acid, News of the Acad. of Sci. Chem. Ser. 12 (2018) 2290-2296.

[17] V.M. Tiunov, O.V. Chugunova, D.V. Grashchenkov, Features of the development of diets for preschool children in celiac patients, Proc. of Voronezh State Univer. of Engineer. Technol. 80(2) (2018) 211-219. Retrieved from: https://doi.org/10.20914/2310-12022018-2-211-219

[18] B. Tohiriyon, V.M. Poznyakovskii, Biologically active complex multifactorial support of the central nervous system, Proc. of Voronezh State Univer. of Engineer. Technol. 80(3) (2018) 185-189. Retrieved from: https://doi.org/10.20914/2310-1202-2018-3185-189

[19] L.V. Ulyanova, V.S. Ledneva, N.S. Burdina et al., 2019 Study of the effectiveness of supplementary feeding in patients with inherited enzyme deficiency, Proc. of Voronezh State Univer. of Engineer. Technol. 81(2) 239-244. Retrieved from: https://doi.org/10.20914/2310-1202-2019-2-239-244

[20] O.F. Fazullina, I.B. Perova, E.V. Rylina, K.I. Eller, Development of approaches to the selection of natural biologically active dietary substances for use as part of biologically active food additives, Food issues 87(S5) (2018) 64-65. 